\title{
An Improved Reconstruction of Total Marine Fisheries Catches for the New Hebrides and the Republic of Vanuatu, 1950-2014
}

\begin{abstract}
Marc Léopold ${ }^{1}$, Gilbert David ${ }^{2}$, Jason Raubani ${ }^{3}$, Jeremie Kaltavara ${ }^{3}$, Lincoln Hood ${ }^{4 *}$ and Dirk Zeller ${ }^{5}$

1 UMR ENTROPIE Ecologie Marine Tropicale des Océans Pacifique et Indien, Institut de Recherche pour le Développement (IRD), Sète, France, ${ }^{2}$ UMR ESPACE-DEV Espace Pour le Développement, Institut de Recherche pour le Développement (IRD), Montpellier, France, ${ }^{3}$ Vanuatu Fisheries Department, Port-Vila, Vanuatu, ${ }^{4}$ Sea Around Us, Institute for the Oceans and Fisheries, University of British Columbia, Vancouver, BC, Canada, ${ }^{5}$ Sea Around Us, School of Biological Sciences, University of Western Australia, Perth, WA, Australia
\end{abstract}

For many small island nations, fisheries provide residents with both food security and economic stability. However, in order to create effective and sustainable fisheries policies

OPEN ACCESS

Edited by:

Annadel Salvio Cabanban, PRIMEX/ANZDEC, Philippines

Reviewed by:

Dimitrios K. Moutopoulos, Technological Educational Institute of

Messolonghi, Greece

Brett W. Molony,

Government of Western Australia,

Australia

*Correspondence:

Lincoln Hood

I.hood@oceans.ubc.ca

Specialty section:

This article was submitted to

Marine Fisheries, Aquaculture and

Living Resources,

a section of the journal Frontiers in Marine Science

Received: 21 June 2017

Accepted: 06 September 2017

Published: 06 October 2017

Citation:

Léopold M, David G, Raubani J, Kaltavara J, Hood L and Zeller D (2017) An Improved Reconstruction of Total Marine Fisheries Catches for the New Hebrides and the Republic of Vanuatu, 1950-2014.

Front. Mar. Sci. 4:306. doi: 10.3389/fmars.2017.00306 and management that will ensure a growing population can prosper, policy makers need to know what is being fished and how much is fished. Vanuatu, the smallest country in Melanesia, has a declared and claimed Exclusive Economic Zone (EEZ) of over 820,000 $\mathrm{km}^{2}$ and fisheries resources play a large part in the food security and economic stability of this country. This reconstruction of the total marine fisheries catch of Vanuatu for 1950-2014 faced major data gaps. It showed that the reconstructed total catches of nearly 1.4 million tonnes (metric tons) 40\% higher than the 977,997 tonnes reported by the Food and Agriculture Organization (FAO) on behalf of Vanuatu for the same period. However, if large-scale industrial catches are excluded, the reconstructed small-scale fisheries catches ( 270,000 tonnes) were over 200\% higher than the 114,862 tonnes of reported catch that were assumed to represent the small-scale sector in FAO data. Subsistence catches made up almost 93\% of small-scale catches, followed by artisanal and recreational catches with $\sim 7$ and $<1 \%$, respectively. By continuously improving the fisheries data of Vanuatu for both the past and the present, policy makers, stakeholders, and fishers can make better decisions that will maintain the benefits of marine fishery resources.

\section{Keywords: unreported catches, small-scale fisheries, artisanal fisheries, subsistence fisheries, Vanuatu}

\section{INTRODUCTION}

Vanuatu (former New Hebrides) is a Pacific island country consisting of 117 islands (73 permanently inhabited) located between $13^{\circ} 04^{\prime}-20^{\circ} 15^{\prime} \mathrm{S}$ and $166^{\circ} 32^{\prime}-170^{\circ} 14^{\prime} \mathrm{E}$ (Seto et al., 2017; Figure 1). The country became independent in 1980 from the French-British condominium established in 1906. Vanuatu's land extends over $12,000 \mathrm{~km}^{2}$, which makes it the smallest country in Melanesia. Vanuatu's Exclusive Economic Zone (EEZ) was declared in 1982 and covers over $820,000 \mathrm{~km}^{2}$, including the area disputed with New Caledonia (Figure 1). In line with standard Sea Around Us procedures (Zeller et al., 2016), any catches by Vanuatu fishers within the disputed 


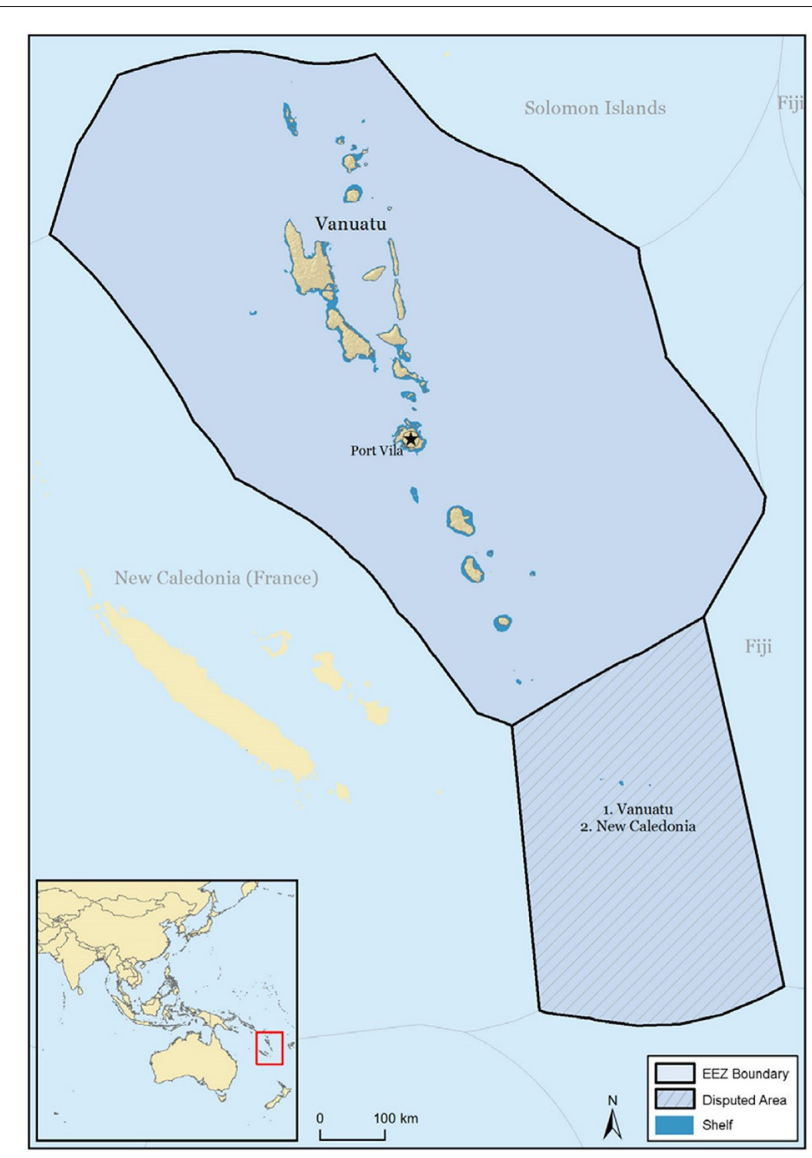

FIGURE 1 | Exclusive Economic Zone (EEZ) and shelf waters to $200 \mathrm{~m}$ depth of Vanuatu. Source: Sea Around Us (http://www.seaaroundus.org/).

EEZ area was here deemed to be part of Vanuatu catches, while any French/New Caledonian catches in this area forms part of New Caledonia's reconstruction (Harper et al., 2009). Since the EEZ makes up almost $99 \%$ of the total land and maritime area of Vanuatu, it only makes sense that according to the Vanuatu 2010 house hold income and expenditure survey (HIES) more than three quarters of the adult population is involved in at least one form of fishing (Pauly and Zeller, 2017). The marine fisheries of Vanuatu were previously described, and a preliminary catch reconstruction undertaken by Zylich et al. (2014) for the years 1950-2010, based on limited online reports. Here, the description of the fisheries of Vanuatu is based on the more extensive data sets available locally to the authors, and covers a period of 64 years from 1950 to 2014.

Marine fisheries in Vanuatu's waters include both large-scale (industrial) and small-scale sectors. The offshore large-scale sector targets tuna and tuna-like species, including by-catch species within the EEZ. This industrial sector started in 1957 with the establishment of the South Pacific Fishing Company Limited (SPFC) in Palekula on Santo Island. It was dominated by longliners although some pole-and-line vessels and purse seiners sporadically fished in the area in the 1970s and 2000s, respectively (Nunoo et al., 2014; Pauly et al., in press). The fishery was mainly operated by foreign vessels from Japan, Korea, Taiwan, China, and Fiji under joint-venture or bilateral fishing agreements. The Chinese fleet has been dominant in Vanuatu's EEZ since the 2000s both in terms of vessel numbers and capacity, followed by Taiwan and Fiji, while the domestic fleet has slowly expanded since the mid-1990s.

The coastal small-scale sector is composed of two sub-sectors, (i) the deep-bottom, and (ii) the shallow water fisheries. On the one hand, the deep-bottom fisheries developed in Vanuatu in 1980 as part of an ambitious, foreign-aided fishing development program (VFDP, Village Fisheries Development Program). This program aimed at targeting previously unexploited resources of snappers and groupers that inhabit deeper waters (100-450 m) using drop lines and bottom longlines. This program initiated commercial fishing activities in the country, and supplies local urban markets on Santo and Efate islands. On the other hand, the shallow water fisheries include small-scale export and nonexport fisheries. Export fisheries mainly target valuable coral reef invertebrate resources, namely trochus (Tectus niloticus), green snail (Turbo marmoratus), and sea cucumbers ( $\sim 20$ species belonging to Holothuriidae and Stichopodidae), for commercial purpose. There are also anecdotal reports of export of lobster and deep-bottom fish, however in this report we only considered trochus, green snail, and sea cucumbers to be exported. Nonexport fisheries are dominated by subsistence and artisanal fishing activities of rural households that target reef finfish and invertebrate species for local consumption and sale. Recreational coastal and big-game fishing charters are limited to a few boats operating from Luganville and Port-Vila urban areas. Recreational catches (although unreported) were not estimated here due to their very low anticipated level relative to the other fisheries that target the same species in Vanuatu's waters.

\section{MATERIALS AND METHODS}

The total marine fisheries catches for Vanuatu's waters were estimated for the offshore large-scale and coastal small-scale sectors separately.

\section{Offshore Large-Scale Sector}

Catch records in Vanuatu waters were provided in Jacquet (2016) and Grandperrin and Brouard (1983) for 1957-1981. No large-scale, industrial fishing is thought to have occurred in this area prior to 1957. Annual catches from 1982 to 1999 were reported in Vanuatu Fisheries Department (VFD) national reports (Amos, 2007). As an approximation, linear interpolation was performed for filling data gaps in 1991-1992 because we did not find evidence of noticeable and short-lasting change in fishing operations at that period in available reports. Records of the Western and Central Pacific Fisheries Commission (WCPFC) were used as estimates of the annual catches in the Vanuatu EEZ since 2000 as reported in VFD national reports to the WCPFC (VFD, 2009, 2015; Nunoo et al., 2014). The reports cover the fishing activities in the Vanuatu EEZ and operations of the Vanuatu flag vessels that were active in the WCPFC and other regional fisheries management organization (RFMO) areas. They mainly focus on the fleet structure, annual catch estimates and 
catch/effort distributions. These data were originally collected and supplied in logbooks and extrapolated based on logbook coverage rates with the assistance of the Secretariat of the Pacific Community. Although discarded catch associated with the largescale tuna and billfish fisheries in Vanuatu waters likely occurred as in other ocean basins, such data were not included here.

The taxonomic composition of catches was provided by Naviti (2005); Amos (2007) and VFD (2009, 2014, 2015) for 1980-2014 for the three main commercial species: albacore tuna (Thunnus alalunga), yellowfin tuna (Thunnus albacares), and bigeye tuna (Thunnus obesus). The bycatch of billfish species (Istiophoridae and Xiphiidae) was also provided in the above sources. As an approximation for earlier years (1958-1979), the average catch composition for 1980-1986 was used for the 1958-1979 period. This was supported by Jacquet (2016), who mentioned that average albacore catch represented about $70 \%$ of total annual catches in the pre-1982 period.

Shark catches were estimated separately from bycatch species because exports of dried shark fins were high when the SPFC operated in Vanuatu, but thereafter decreased substantially. We therefore assumed that they have been low since 1987 although there is no record that supports that hypothesis. Export records of dried shark fins were provided by Amos (2007) for 19801986 and averaged $0.26 \%$ (range: $0.1-0.4 \%$ ) of tuna and billfish landings. As an approximation, this ratio was used to estimate dried fin exports for 1958-1979 based on reported tuna and billfish landings given that the nature of fishing operations within the large-scale sector was broadly similar over that period. The derived tonnages of dried fins were multiplied by 77.5 to estimate corresponding wet weight shark catches using the mean conversion rates from wet to dry fin mass $(43 \%)$ and from round mass to wet fin mass (3\%) provided by Biery and Pauly (2012).

Although the coastal small-scale sector also occasionally targets the same species as the offshore sector, available data (e.g., Amos, 2007) suggested that its contribution to total tuna catch and associated bycatch in Vanuatu's waters has been very small (i.e., $\sim 0.1 \%,<10$ tonnes/year). Consequently, these catches of the small-scale sector were not included in our tuna catch reconstruction.

\section{Coastal Small-Scale Sector}

Although Vanuatu's public institutions attach great importance to the development of subsistence and commercial (artisanal) small-scale fisheries, they present great difficulties for the collection of catch information (Gillett, 2010). For the purpose of this study, the coastal small-scale sector was structured into two sub-sectors, i.e., deep and shallow water fisheries. The latter sub-sector was further separated into export and non-export fisheries.

\section{Deep-Bottom Fisheries}

The deep-bottom fishery has been monitored by the VFD and foreign research agencies (e.g., Institut de Recherche pour le Développement, IRD, France, formerly known as ORSTOM) since its early stage of development. Deep-bottom catches were therefore estimated using commercial landing statistics available in Schaan et al. (1987) for 1982, David and Cillaurren (1988) for
1983-1987, Amos (2007) for 1988-1999, and the VFD database for 2000-2014. Since available reports and literature did not provide evidence of discards in this fishery, we assumed that it created very little if any discarded catch. To account for missing statistics for some provinces of Vanuatu for 1993-1995 and 1999, we calculated the average catch from the years with catch data for an individual province to estimate the missing annual production for that province. This was repeated for each province and then all provinces summed to get an approximation of the estimated total annual catch for all provinces combined. Furthermore, deep-bottom catches have not been comprehensively recorded by the VFD throughout the country since 2000. Although a data collection system was put in place by the VFD using duty-free fuel as an incentive for fishers to submit catch data, not all fishers involved in this fishery have participated. Based on local evidence of deep-bottom fishing activities, we therefore used the annual records in 1999 as a rough and uncertain approximation of the annual production for the 2001-2014 period.

The taxonomic composition of deep-bottom catches was reliably monitored during the 1980-1991 period (Brouard and Grandperrin, 1984; Cillaurren et al., 2001). For the 19821984 period, taxonomic information was also available from Schaan et al. (1987). The fishery mainly targeted 11 species of snappers (family Lutjanidae) and groupers (Serranidae), which contributed $70-95 \%$ of annual deep-bottom catch. Ninety-six other species belonging to 29 families were identified in the bycatch of this multispecies fishery, including sharks (Brouard and Grandperrin, 1984; Table 1). The same species breakdown as that of the 1980-1991 period was used for the 1992-2014 period to roughly approximate the taxonomic composition of more recent catches, although no taxonomic survey was available to support that assumption (Table 2).

\section{Shallow Water Export Fisheries}

We used export statistics as a reliable proxy for the annual catches of exported invertebrate species, and treated these catches as artisanal in nature (i.e., small-scale, commercial). Sea cucumbers are not consumed in Vanuatu, while trochus and green snail shells are sold for export although their flesh is consumed locally.

Export records for trochus were available from Devambez (1959, 1960) for 1950-1960, from Brouard and Grandperrin (1984) for 1969-1982 and from the VFD for 1983-2012. Linear interpolation was performed for filling the data gaps (19611968, 1983-1984, and 1999-2000) as an approximation although available records suggested that annual exports occasionally highly varied between consecutive years (e.g., in the 1970s). We used the reported catch in 2012 as a rough estimate of the annual catch in 2013 and 2014. The trochus shell export tonnages were converted to whole, wet weight of trochus using a conversion factor of 1.51, assuming that each ton of trochus shell represents $49 \%$ of raw trochus (Teh et al., 2014).

Reliable sea cucumber export data were available from the VFD for 1983-2014. Sporadic exports may have occurred between 1950 and 1983 as the fishery started in the region in the nineteenth century, although no records are available. Since sea cucumbers were processed, dried and reported as bêche-demer without species reference, we used a multispecies conversion 
TABLE 1 | List of bycatch species of the coastal deep-bottom fisheries in Vanuatu.

\begin{tabular}{lc}
\hline Taxon & Number of species \\
\hline BONY FISHES & \\
Etilidae & 14 \\
Lutjanidae & 17 \\
Serranidae & 20 \\
Lethrinidae & 8 \\
Carangidae & 6 \\
Pentapodidae & 5 \\
Labridae & 1 \\
Emmelichthyidae & 1 \\
Sphyraenidae & 5 \\
Holocentridae & 2 \\
Priacanthidae & 2 \\
Branchiostegidae & 1 \\
Triglidae & 1 \\
Gempylidae & 3 \\
Scombridae & 1 \\
Plymixiidae & 1 \\
Bramidae & 1 \\
Triodontidae & 1 \\
Chimaeridae & 1 \\
Echeneidae & 1 \\
Congridae & 1 \\
SHARKS & 1 \\
Carcharhinidae & 1 \\
Triakidae & 1 \\
Alopiidae & 1 \\
Spinacidae & 1 \\
Hexanchidae & 1 \\
Lamnidae & 1 \\
Squalidae & 1 \\
\hline Total & 1 \\
\hline Sorce:Brol & 1 \\
\hline & 1 \\
\hline
\end{tabular}

Source: Brouard and Grandperrin (1984).

factor, i.e., dried weight $=7 \%$ wet weight to estimate the wet weight of the corresponding exports of bêche-de-mer.

Data on green snail exports were available from Van Pel (1956) for 1950-1956, from Brouard and Grandperrin (1984) for 1969-1980 and from Amos (2007) for 1986-2004. The fishery was effectively closed in 2005 for 15 years. Linear interpolation was performed for years without data (1956-1968 and 19811985 ) as a rough approximation although there was no fishery information to support that assumption. Green snail export tonnages were converted to whole, wet weight of green snails using the same conversion rate as used for trochus shells.

\section{Shallow Water Non-export Fisheries}

Shallow water catches that were not destined for export were estimated using the results of the large-scale socioeconomic survey conducted in 1983-1984 (David, 1991). To date, this study has been the only country-wide survey of shallow water fisheries in Vanuatu. These fisheries target coral reef and coastal pelagic
TABLE 2 | Estimated taxonomic breakdown of the finfish catches of the deep-bottom fisheries in Vanuatu, 1950-2014.

\begin{tabular}{|c|c|c|c|c|c|c|}
\hline \multirow[t]{2}{*}{ Taxon } & \multicolumn{6}{|c|}{ Catch composition (proportional by weight) } \\
\hline & $1982^{a}$ & $1983^{b}$ & $1984^{b}$ & $1985^{b}$ & $1986^{b}$ & $1987-2014^{c}$ \\
\hline \multicolumn{7}{|l|}{ LUTJANIDAE } \\
\hline Aphareus rutilans & 0.011 & 0.000 & 0.016 & 0.014 & 0.015 & 0.021 \\
\hline Etelis carbunculus & 0.200 & 0.308 & 0.115 & 0.189 & 0.189 & 0.294 \\
\hline Etelis coruscans & 0.110 & 0.095 & 0.091 & 0.145 & 0.110 & 0.167 \\
\hline Etelis radiosus & 0.029 & 0.023 & 0.039 & 0.027 & 0.028 & 0.028 \\
\hline Lutjanus malabaricus & 0.061 & 0.051 & 0.091 & 0.062 & 0.039 & 0.080 \\
\hline Pristimoides filamentosus & 0.044 & 0.012 & 0.070 & 0.031 & 0.064 & 0.055 \\
\hline Pristimoides flavipinnis & 0.053 & 0.058 & 0.053 & 0.046 & 0.053 & 0.064 \\
\hline Pristimoides multidens & 0.145 & 0.129 & 0.178 & 0.130 & 0.143 & 0.156 \\
\hline \multicolumn{7}{|l|}{ SERRANIDAE } \\
\hline Epinephelus magniscuttis & 0.022 & 0.010 & 0.022 & 0.032 & 0.023 & 0.023 \\
\hline Epinephelus morrhua & 0.021 & 0.019 & 0.022 & 0.021 & 0.021 & 0.019 \\
\hline Epinephelus septemfasciatus & 0.018 & 0.009 & 0.016 & 0.017 & 0.030 & 0.047 \\
\hline Sub-total (11 species) & 0.713 & 0.713 & 0.713 & 0.713 & 0.713 & 0.952 \\
\hline Others & 0.287 & 0.287 & 0.287 & 0.287 & 0.287 & 0.048 \\
\hline
\end{tabular}

${ }^{a}$ Average of 1983-1986 rates.

bschaan et al. (1987).

${ }^{c}$ Cillaurren et al. (2001).

resources over fishing grounds to $\sim 100 \mathrm{~m}$ depth. Resources consist of a very large diversity of species of finfish (i.e., over 370 species from 32 families) and over 60 species of mollusks, echinoderms and crustaceans (Van Pel, 1956; Cillaurren et al., 2001; Amos, 2007; Friedman et al., 2008; Poupin and Juncker, 2010; Beckensteiner, 2011; Jimenez et al., 2011). We assumed that shallow water non-export fisheries created very little if any discarded catch.

The annual average catch per rural fishing household in Vanuatu in 1984 was estimated by David (1991) by dividing the annual catches of shallow water fisheries by the number of rural households engaged in fishing in 1984, and included the associated 95\% confidence interval of this estimate. As an approximation, we assumed that this level of catch has been steady for the entire study period, although the technological, economic, and urban development has affected fish production and effective reporting over the last $60+$ years. Indeed, our assumption is supported by the fact that any potential change in annual household catch has likely been (at least partially) mitigated by three factors. Firstly, the last agricultural census (VNSO, 2007) provided evidence that subsistence fishing still dominates coastal fishing activities in Vanuatu and that the overall proportion of rural fishing household engaged in commercial activities has not increased since the 1980s (i.e., around 30\%). This survey suggested that households go fishing primarily for self-consumption and occasional sale, resulting in only slight changes of household needs for marine products since the 1980s, as confirmed also by Johannes and Hickey (2004) and Léopold et al. (2013). Secondly, the shallow water fisheries production was proportional to fishing effort (in number of fishing trips) across 11 island groups in 1984 (David, 1991; Figure 2). This linear relationship suggests that shallow water 


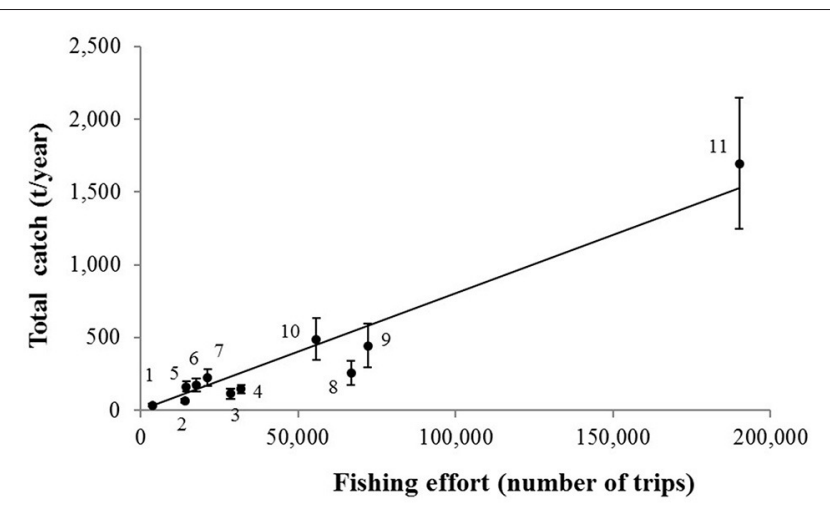

FIGURE 2 | Regression ( $y=0.008 x, R^{2}=0.927$ ) of estimated total annual catch and fishing effort of the shallow water fisheries not destined for export in 11 island groups in Vanuatu in 1984. Conservative 95\% confidence intervals are represented. The taxonomic composition of the catch includes finfish, mollusks and lobsters. Derived from data from David (1991). (1) Paama Island; (2) Ambrym Island; (3) Ambae \& Maewo Island; (4) Sheperds Island; (5) Pentecost Island; (6) Epi Island; (7) Sanma Province; (8) Torba Province; (9) Tafeo Province; (10) Efate Island; (11) Malekula Island.

resources were not overexploited at the country scale at that time, and consequently that production could likely be increased by increasing fishing effort, conditionally to the spatial allocation of that additional fishing pressure. Thirdly, although the increasing use of more effective gears (i.e., gillnets, waterproof torches for night spear fishing) may have had a positive influence on individual fishing yields, the increasing total fishing pressure due to human population growth in coastal villages may have, at least partially counterbalanced this effect.

The annual average catch per rural fishing household was derived from David (1991) separately for fish, shellfish, lobsters, and octopus. The total annual catch of each taxonomic group was then inferred from the average annual household catch of this species group and the total number of rural fishing households each year between 1950 and 2014. The latter was estimated by multiplying the total number of rural households by the percentage of these households that was engaged in fishing. The number of rural households in Vanuatu was obtained from national population census in 1967, 1979, 1989, 1999, and 2009 (VNSO, 2009). Household data for years between census years were linearly interpolated. We used the World Bank's model of Vanuatu rural population (http://donnees. banquemondiale.org/) and average household size over the 19671979 period to estimate the number of annual rural households for 1950-1966. The percentage of rural households engaged in fishing was available from David (1991) for 1979 and 1984, and from VNSO (2007) for 1992 and 2007. Percentage data for years without surveys were linearly interpolated. As an approximation the average percentage of rural households engaged in fishing between 1979 and 1984 was used as an estimate of the annual rate for each year between 1950 and 1978.

The total annual catch of each taxonomic group was further broken down into family-level taxa. A conservative percentage range was used in the family breakdown of each group to account for the very large number of target species (particularly for fish), important data gaps, and inherent strong inter-annual variability of small-scale fishing activities (Table 3).

\section{RESULTS}

\section{Offshore Large-Scale Sector}

The offshore large-scale sector displayed two main periods that highlighted an up-and-down developing trend (Figure 3). During the first phase (1957-1986), all offshore catches by the SPFC and foreign vessels were landed at Palekula transshipment base on Esperitu Santo Island. Total catches ranged between 1,600 and 15,600 tonnes/year. These facilities were closed in 1986 as the SPFC ceased its activities following the drop of fishing yields and the establishment of the EEZ. During the second phase (1987-2013) most of the catch was directly delivered to Fijian, Papua New Guinean and American Samoan ports. Total catches ranged between 1,500 and 13,800 tonnes/year (Figure 3). The fishery was characterized by an expansion of fishing effort until 2006 but then decreased until 2014 due to the relocation of the foreign fleets to the Solomon Islands in particular.

The estimated catch composition has been dominated by albacore tuna (52-94\%), yellowfin tuna (3-31\%), and bigeye tuna $(1-14 \%)$ for the entire period (Figure 3 ). Other important tuna and billfish species caught in the Vanuatu EEZ are skipjack (Katsuwonus pelamis), black marlin (Makaira indica), blue marlin (Makaira nigricans), striped marlin (Tetrapturus audax), and swordfish (Xiphias gladius). The main shark species caught as bycatch include blue shark (Prionace glauca), silky shark (Carcharhinus falciformis), oceanic whitetip shark (Carcharhinus longimanus), and mako shark (Isurus spp.). Catches of other shark species and other finfish species (e.g., dolphinfish Coryphaena hippurus) have not been explicitly recorded, although they have been sporadically reported by onboard observers from the VFD since 2009.

\section{Coastal Small-Scale Sector Deep-Bottom Fishery}

Catches of the deep-bottom fishery increased rapidly after its start in 1980, peaked at 130 tonnes in 1986, which was followed by a highly variable catches of between 50 and 100 tonnes/year on a generally declining trend until the late 1990s (Figure 4). More recently, catches are thought to have been much lower at around 27-30 tonnes/year (Figure 4).

\section{Shallow Water Export Fisheries}

Export catches of trochus, sea cucumber and green snail initially displayed an overall increasing trend since 1970 with a peak in total catches of these three taxa in 1992 (Figure 5). However, after 1992, catches began to decline. Specifically, the sea cucumber fisheries followed a typical boom-and-bust cycle and collapsed in the early 2000s. The green snail fisheries collapsed in the mid1990s after decades of exploitation. Exports of trochus shells have declined to levels of around a quarter of those in previous decades (Figure 5). 
TABLE 3 | Derived taxonomic composition of the finfish, lobster, octopus, and shellfish catches for the shallow water fisheries in Vanuatu, 1950-2014.

\begin{tabular}{|c|c|c|c|c|c|}
\hline \multirow[t]{2}{*}{$\begin{array}{l}\text { Target } \\
\text { group }\end{array}$} & \multirow[t]{2}{*}{ Familya } & \multirow[t]{2}{*}{$\begin{array}{c}\text { Number of } \\
\text { species }\end{array}$} & \multicolumn{3}{|c|}{$\begin{array}{c}\text { Estimated catch } \\
\text { composition ( } \% \text { weight) }\end{array}$} \\
\hline & & & Minimum & Maximum & Average \\
\hline Finfish $^{b}$ & & 372 & & & \\
\hline \multirow{17}{*}{$\begin{array}{l}\text { Main } \\
\text { targets }\end{array}$} & Acanthuridae & 28 & 1.0 & 10 & 5.0 \\
\hline & Balistidae & 10 & 3.0 & 10 & 5.0 \\
\hline & Belonidae & 2 & 3.0 & 10 & 5.0 \\
\hline & Carangidae & 13 & 3.0 & 10 & 5.0 \\
\hline & Haemulidae & 7 & 3.0 & 10 & 5.0 \\
\hline & Hemiramphidae & 1 & 3.0 & 10 & 5.0 \\
\hline & Holocentridae & 21 & 3.0 & 10 & 5.0 \\
\hline & Kyphosidae & 1 & 3.0 & 10 & 5.0 \\
\hline & Labridae & 81 & 3.0 & 10 & 5.0 \\
\hline & Lethrinidae & 10 & 3.0 & 10 & 5.0 \\
\hline & Lutjanidae & 19 & 3.0 & 10 & 5.0 \\
\hline & Mugilidae & 5 & 3.0 & 10 & 5.0 \\
\hline & Mullidae & 11 & 3.0 & 10 & 5.0 \\
\hline & Scaridae & 21 & 3.0 & 10 & 5.0 \\
\hline & Serranidae & 49 & 3.0 & 10 & 5.0 \\
\hline & Siganidae & 6 & 3.0 & 10 & 5.0 \\
\hline & Sphyraenidae & 2 & 3.0 & 10 & 5.0 \\
\hline \multirow{15}{*}{$\begin{array}{l}\text { Secondary } \\
\text { targets }\end{array}$} & Albulidae & 2 & 0.1 & 3 & 1.0 \\
\hline & Atherinidae & 2 & 0.1 & 3 & 1.0 \\
\hline & Carcharhinidae & 5 & 0.1 & 3 & 1.0 \\
\hline & Chaetodontidae & 31 & 0.1 & 3 & 1.0 \\
\hline & Chanidae & 1 & 0.1 & 3 & 1.0 \\
\hline & Clupeidae & 3 & 0.1 & 3 & 1.0 \\
\hline & Dasyatidae & 3 & 0.1 & 3 & 1.0 \\
\hline & Diodontidae & 2 & 0.1 & 3 & 1.0 \\
\hline & Ephipiddae & 2 & 0.1 & 3 & 1.0 \\
\hline & Gerreidae & 2 & 0.1 & 3 & 1.0 \\
\hline & Nemipteridae & 5 & 0.1 & 3 & 1.0 \\
\hline & Ostraciidae & 4 & 0.1 & 3 & 1.0 \\
\hline & Pomacanthidae & 18 & 0.1 & 3 & 1.0 \\
\hline & Priacanthidae & 4 & 0.1 & 3 & 1.0 \\
\hline & Scombridae & 2 & 0.1 & 3 & 1.0 \\
\hline \multirow[t]{3}{*}{ Lobster ${ }^{c}$} & & 7 & & & \\
\hline & Palinuridae & 5 & 80.0 & 99 & 90.0 \\
\hline & Scyllaridae & 2 & 1.0 & 20 & 10.0 \\
\hline \multirow[t]{2}{*}{ Octopus $^{d}$} & & 1 & & & \\
\hline & Octopodidae & 1 & 100.0 & 100 & 100.0 \\
\hline Shellfish $^{d}$ & & 43 & & & \\
\hline \multirow[t]{6}{*}{ Bivalves } & Arcidae & 1 & 0.1 & 10 & 5.3 \\
\hline & Cardiidae & 4 & 0.1 & 10 & 5.3 \\
\hline & Mytilidae & 1 & 0.1 & 10 & 5.3 \\
\hline & Ostreidae & 2 & 0.1 & 10 & 5.3 \\
\hline & Pterridae & 1 & 0.1 & 10 & 5.3 \\
\hline & Spondylidae & 2 & 0.1 & 10 & 5.3 \\
\hline
\end{tabular}

(Continued)
TABLE 3 | Continued

\begin{tabular}{|c|c|c|c|c|c|}
\hline \multirow[t]{2}{*}{$\begin{array}{l}\text { Target } \\
\text { group }\end{array}$} & \multirow[t]{2}{*}{ Familya } & \multirow[t]{2}{*}{$\begin{array}{c}\text { Number of } \\
\text { species }\end{array}$} & \multicolumn{3}{|c|}{$\begin{array}{c}\text { Estimated catch } \\
\text { composition ( } \% \text { weight) }\end{array}$} \\
\hline & & & Minimum & Maximum & Average \\
\hline & Tellinidae & 2 & 0.1 & 10 & 5.3 \\
\hline & Veneridae & 5 & 0.1 & 10 & 5.3 \\
\hline \multirow[t]{11}{*}{ Gastropods } & Fasciolariidae & 2 & 0.1 & 10 & 5.3 \\
\hline & Muricidae & 2 & 0.1 & 10 & 5.3 \\
\hline & Naticidae & 2 & 0.1 & 10 & 5.3 \\
\hline & Neritidae & 4 & 0.1 & 10 & 5.3 \\
\hline & Patellidae & 1 & 0.1 & 10 & 5.3 \\
\hline & Planaxidae & 1 & 0.1 & 10 & 5.3 \\
\hline & Strombidae & 5 & 0.1 & 10 & 5.3 \\
\hline & Tegulidae & 2 & 0.1 & 10 & 5.3 \\
\hline & Terebridae & 1 & 0.1 & 10 & 5.3 \\
\hline & Turbinidae & 4 & 0.1 & 10 & 5.3 \\
\hline & Vermetidae & 1 & 0.1 & 10 & 5.3 \\
\hline
\end{tabular}

\section{Shallow Water Non-export Fisheries}

Our reconstruction suggested that shallow water catches for household and local use (i.e., subsistence and local artisanal catches) have followed an increasing trend over time throughout the country, which is entirely driven by the growth in and distribution of the rural human population in coastal villages (Figure 6). Total estimated catches increased by $480 \%$ from 1,400 tonnes in 1950 to 6,700 tonnes in 2014, resulting in an increase in area catch rate from 3.2 to 15 tonnes $/ \mathrm{km}^{2}$. In 2014, estimated shallow catches reached 3,100 $\pm 1,300$ tonnes of finfish, 2,100 \pm 260 tonnes of shellfish, 1,300 \pm 300 tonnes of lobsters and $150 \pm$ 25 tonnes of octopus (Figure 6). Overall finfish represented $46 \%$ of total reconstructed shallow water catches followed by shellfish (32\%), lobsters (20\%), and octopus (2\%).

\section{Total Catch}

Combining the reconstructed catches from the individual components detailed above, suggests a total reconstructed catch over the 1950-2014 time period of nearly 1.4 million tonnes. This contrasts with reported catches of 977,997 tonnes over the same time period. Thus, reconstructed total catches were over $40 \%$ higher than reported data would suggest. This positive difference was attributed to large-scale industrial catches $(+230,000$ tonnes, $+100 \%)$ and small-scale fisheries catches $(+150,000$ tonnes, + $200 \%$ ), respectively.

\section{DISCUSSION}

Overall, the catch reconstruction for Vanuatu suggests that the development of fishing sectors initiated 35 years ago at the time of independence of Vanuatu has not been an unmitigated success. The deep-bottom and offshore fisheries remain underexploited or dominated by foreign fleets, respectively. Thus, 


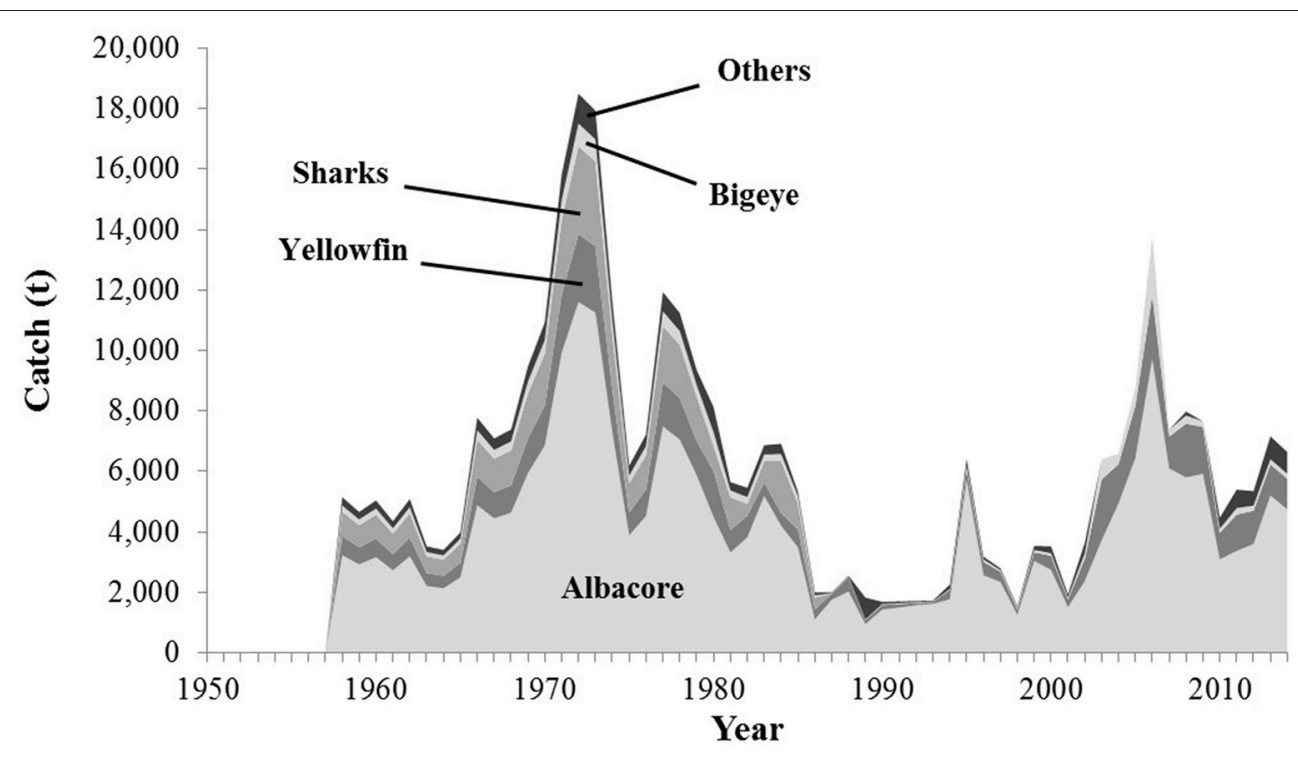

FIGURE 3 | Total reconstructed offshore large-scale catches as derived here for Vanuatu waters, 1950-2014 by major taxonomic group. Others includes bycatch species such as, marlins.

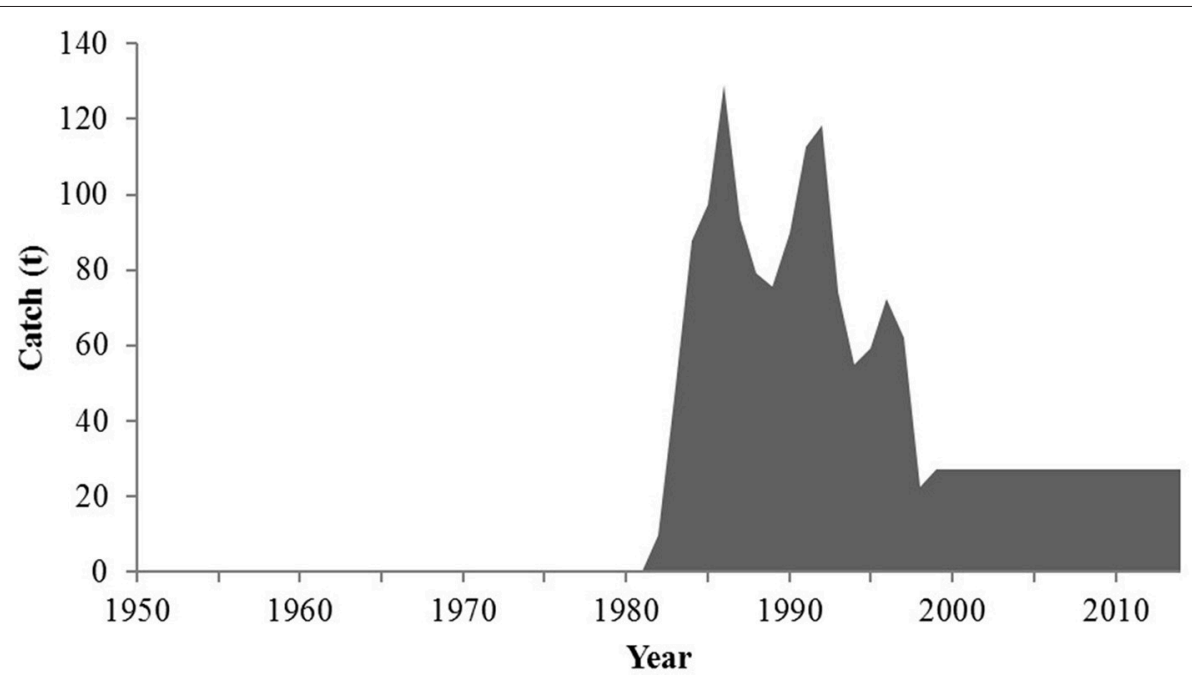

FIGURE 4 | Total reconstructed deep-bottom catches (included bycatch) in Vanuatu waters, 1950-2014.

neither fishery contributes as strongly as expected to the country's economy (David, 2014). In recent years, the non-export fisheries, and the coral reef fisheries in particular have likely contributed the most to the domestic fishing sector, which is the main livelihood and food security contributor of all the fisheries in Vanuatu.

\section{Large-Scale Fisheries}

The reconstruction of the offshore catches for tuna and billfishes (and sharks) exhibited differences with FAO fisheries statistics. In total the reconstructed large-scale industrial catches (over 1.1 million tonnes) were $127 \%$ higher than the 865,000 tonnes reported by the FAO on behalf of Vanuatu for the same period. Difference in annual estimates ranged between 0 and
17,000 tonnes (3,600 tonnes on average). This is due to the fact that FAO fisheries statistics consider the catch of all Vanuatu-flagged fishing vessels as catch of Vanuatu, with no consideration given to the spatial location (e.g., EEZ) of catches beyond the extremely broad FAO statistical areas. This flag-state-only focus has two implications. First, the catches that occurred during the first phase of the development of the industry in the waters surrounding Vanuatu (and the former New-Hebrides) have not been reported in FAO statistics for Vanuatu, as they were taken by foreign flagged vessels. Second, some of the Vanuatu-flagged vessels (i.e., purse seiner and pole-and line vessels) whose catches exceeded those of the longliners have not operated in the Vanuatu EEZ since the 1990s. More insidious, the Vanuatu International Shipping Registry 


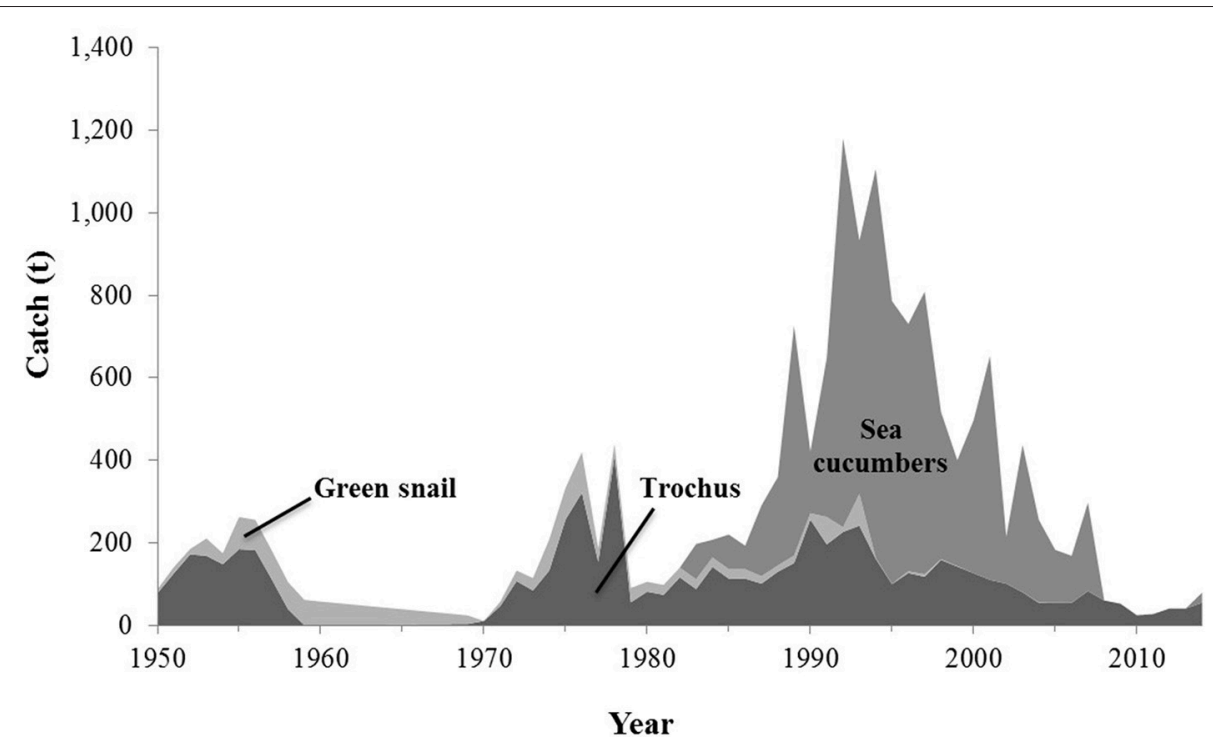

FIGURE 5 | Total reconstructed shallow water catches for export (i.e., artisanal) in Vanuatu, 1950-2014 by major taxonomic groups (all whole, wet weight).

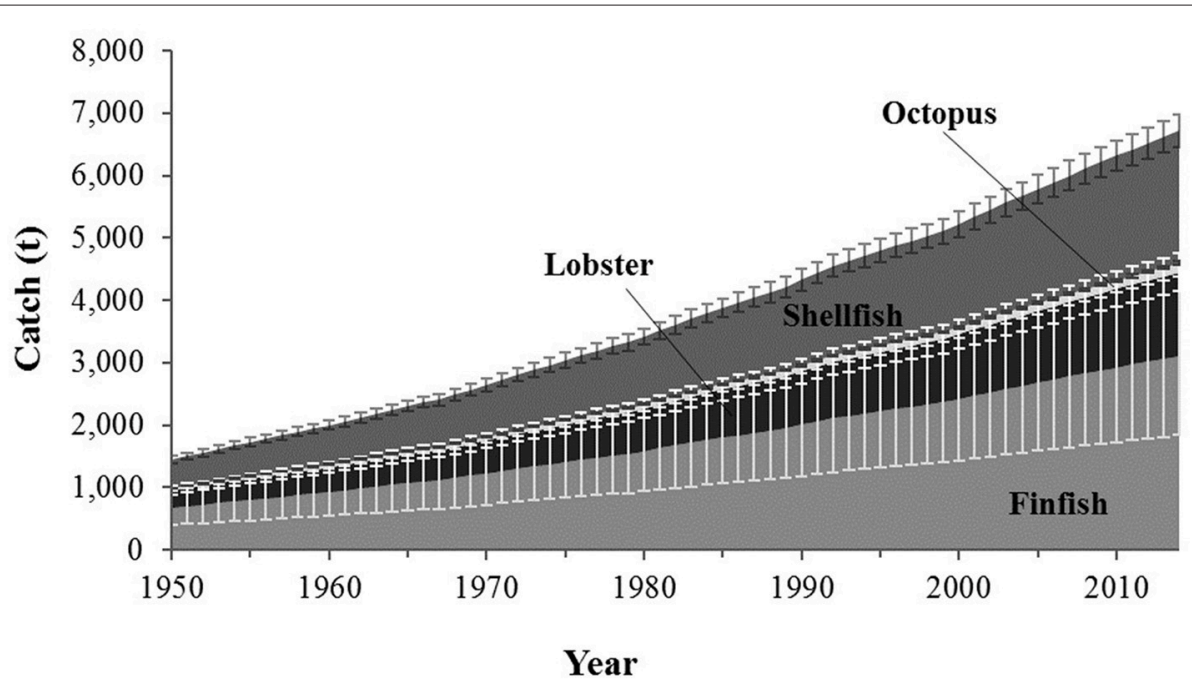

FIGURE 6 | Total reconstructed shallow water catches not for export (i.e., subsistence and local artisanal) in Vanuatu, 1950-2014 by major taxonomic groups. 95\% confidence intervals of estimates are represented.

allows foreign fishing companies to register as Vanuatu-flagged vessels under contract. The result is that Vanuatu is a Flag of Convenience country, which creates substantial problems for proper accounting and global data transparency of fisheries catches. This leads also to considerable misrepresentation of the contribution of fisheries to the food security and livelihood, as well as economic benefits for Vanuatu. As a result, our reconstruction of offshore catches showed that the FAO statistics are not representative of offshore catches in the Vanuatu EEZ over this period. Clearly, both flag-sate accounting as well as spatial representation of fishing are important in data on fisheries, as is being shown by the Sea Around Us (http://www. seaaroundus.org) for all countries in the world (Pauly and Zeller, 2016).

Data uncertainty also affected the reconstruction of offshore catches. For example, longliners from the SPFC were reported to undertake long-distance fishing trips from their Palekula base (Jacquet, 2016). Available information on fishing locations between 1979 and 1981 suggests that only a small part of the SPFC landings (i.e., <10\%) for 1958-1986 may actually have been caught in the immediate waters surrounding Vanuatu. Thus, the reconstruction presented here may have overestimated tuna catch and bycatch in the EEZ waters around Vanuatu between 1958 and 1986. Furthermore, although the use of Vessel 
Monitoring Systems (VMS) on fishing vessels has provided increasing information on the spatial allocation of effort (even if not publicly available), logbook coverage of foreign fishing fleets has been variable across years. Consequently, foreign catches in Vanuatu's EEZ may have been miss-estimated for some years, particularly in the 1990s. Both limitations created uncertainties that should be taken into account when interpreting catch variations in the waters surrounding Vanuatu. This also reinforces the need for better data collection and reporting systems, with both flag-state and detailed spatial dimensions.

Growing attention is given by the VFD and regional agencies (e.g., the Secretariat of the Pacific Community and the Forum Fishing Agency) to fill critical data gaps and to provide more reliable estimates of catches and effort in the Vanuatu EEZ. Catch and fishing effort data have been recorded extensively from the fleets of Vanuatu, Fiji and China since the 2000s. Since 2009, the VFD has also accomplished full on-board observer coverage for the locally-based foreign fishing vessels and full port sampling of fresh fish unloaded in ports, including transshipments. Furthermore, the total number of licenses has been limited to 115 (i.e., 75 foreign access licenses and 40 locallybased foreign licenses) while annual license fee has increased by $50 \%$ to ensure appropriate financial returns to the Vanuatu government.

\section{Small-Scale Fisheries Deep-Bottom Fisheries}

Our reconstruction of deep-bottom catches likely underestimated real withdrawals, particularly since the 2000s. First, deep-bottom fish is occasionally used for self-consumption throughout Vanuatu, although one may reasonably assume that this use of deep-bottom fish represented only a negligible proportion of catches, given the clear market-oriented nature of these fisheries. Second, some catches of the commercial sector have likely been sold directly to households or tourist operators, and thus remained unreported to the VFD. Third, the capacity of the Fisheries Extension Centers for maintaining a reliable and accurate monitoring program throughout the Vanuatu archipelago has varied over the years. In particular, data gaps have increased to an unknown level since the 2000s, despite the role of these fisheries in local economies. Overall, the reconstructed deep-bottom catches should therefore be interpreted as rough approximations.

Yet a plausible interpretation may be hypothesized from estimated trends. The deep-bottom fisheries have not emerged as a structuring fishing sector in Vanuatu as documented since their early stage of development by David and Cillaurren (1992). Variations in catches were likely linked to fluctuations in fishing effort rather than changes in resource abundance except in the vicinity of main urban areas, and the overall economic potential of this sub-sector has likely been maintained. If the deep-bottom fishery is in fact the only not overexploited commercial coastal fishery in Vanuatu, then there is an opportunity here for the government to create a sustainable management plan. This could allow the fishery to grow to a sustainable capacity, and provide a valuable source of protein to communities while increasing the economic contributions and benefits of this fishery. This strongly reinforces the need for maintaining an accurate data collection system for deep bottom catches and fishing effort, including their spatial dimensions.

\section{Shallow Water Export Fisheries}

The shallow water export fisheries have shown an alarming decreasing trend since 1950 following the recurrent exploitation of the valuable invertebrate resources since the nineteenth century. Specifically, the sea cucumber and green snail exports collapsed in the 2000s, leading to national closures in 2008 (for 6 years) and 2005 (projected for 15 years), respectively. Limited catches of sea cucumbers were allowed in 2014 based on species-specific total allowable catches (Léopold, 2016). Trochus resources displayed early signs of depletion as far back as 1957 (Devambez, 1959) and the fishery was consequently closed for 2 years. Overexploitation of trochus resources intensified in the 1980s due to high demand on world markets and resultant increases in purchase prices (Marchandise, 1990). Finally, the number of operational shell-processing factories dropped from six in 1994 to one after 2004. This factory relied on imports of trochus shells in 2014 to maintain production (M. Léopold, pers. obs.) providing evidence of severe resource depletion in most islands of Vanuatu. Reconstructed catch data in $2013(\sim 41$ tonnes) and 2014 ( $\sim 55$ tonnes) therefore likely overestimated real domestic trochus catches within the Vanuatu EEZ.

Management of shallow export fisheries aimed at rebuilding overexploited stocks through strict enforcement of national fishing rules (e.g., size limits, spatially explicit total allowable catch, and rotational fishing closure) is urgently needed in Vanuatu. This would allow at least some of the economic potential of these historical fisheries to recover. Indeed, given the recurrent demand for such shells on world markets, our reconstructed catch patterns predict that these fisheries will not recover and will eventually close if national governing agencies do not actively engage in effective harvest control.

\section{Shallow Water Non-export Fisheries}

The reconstruction of shallow water catches not destined for export (i.e., largely subsistence and local artisanal fisheries) was affected by high uncertainty due to an obvious scarcity of data since the early 1980s, particularly for subsistence activities. Specifically, we assumed that annual household catch rates in rural areas have remained similar for the last 30 years to infer these catches from population census data. Although this seemed reasonable based on available information, whether or not shallow water areas have been able to cope with the estimated increase in fishing effort and resultant catch density since 1984 (e.g., for finfish: from $3.9 \pm 1.6$ tonnes $/ \mathrm{km}^{2}$ in 1984 to $6.9 \pm$ 2.8 tonnes $/ \mathrm{km}^{2}$ in 2014 ) is highly questionable, especially those close to market networks. Updated data on household fishing at national scale is required to estimate their current catch levels across islands. This is particularly important in light of the importance of these largely subsistence oriented fisheries in the Pacific (Zeller et al., 2015).

Such new and improved data would also allow for improving the precision of catch estimates and their taxonomic composition, and for interpreting the increasing trend of 
shallow water non-export catches that was derived here. For instance, estimated catches increased more slowly than Vanuatu's population growth over the period, thus suggesting a decreasing per capita consumption rate from $32 \mathrm{~kg} /$ person in 1950 (all species included) to $26 \mathrm{~kg} /$ person in 2014. Similarly estimated per capita finfish consumption decreased from $14.7 \pm 6 \mathrm{~kg}$ in 1950 to $12.1 \pm 4.9 \mathrm{~kg}$ in 2014 . This trend is driven by the assumed fixed household catch rate and the fact that Vanuatu's overall population growth has been higher than that of the rural population since 1950 . The potentially decreasing trend should be examined in more detail through a new countrywide socioeconomic survey, which should also include marine and land crab fisheries. The latter were not included in our analysis although they constitute important local food and commercial resources.

\section{CONCLUSION}

The reconstruction process faced major data gaps, particularly and unsurprisingly with regards to the composition and the level of the catches of the coastal small-scale sector. Therefore, uncertainty of estimates has been acknowledged. This reconstruction of total marine fisheries catch of Vanuatu for 1950-2014 showed that the reconstructed total catches were $40 \%$ higher than those reported by the FAO on behalf of Vanuatu for the same period. In recent years, this difference was mainly attributed to misreporting of non-export catches. Interestingly we observed different trends in catches among the fisheries studied (i.e., roughly stabilized or slightly decreasing within the large-scale and small-scale deep-bottom fisheries; collapsing within the shallow water export fisheries; and continuously increasing within the shallow water non-export fisheries). The study therefore stresses the need for (i) meaningful management insights for apparently overexploited fisheries such as, export invertebrate fisheries, and (ii) appropriately monitoring developing small-scale fisheries (subsistence and artisanal) to confirm or deny estimated trends and inform management decisions. Although poorly monitored, shallow non-export fisheries have been facing increasing sustainability challenges due to the general population growth and the increasing number of people requiring livelihoods. Given the

\section{REFERENCES}

Amos, M. J. (2007). Vanuatu Fishery Resource Profiles. Apia: Secretariat of the Pacific Regional Environment Programme (SPREP).

Beckensteiner, J. (2011). La Gestion Villageoise des Pêches Récifales sur l'île d'Efaté (Vanuatu): Situations et Enjeux D'après les Savoirs Locaux. M.Sc., Montpellier 2 University.

Biery, L., and Pauly, D. (2012). A global review of species-specific shark fin to body weight ratios and relevant legislation. J. Fish Biol. 80, 1643-1677. doi: 10.1111/j.1095-8649.2011.03215.x

Brouard, F., and Grandperrin, R. (1984). Les Poissons Profonds de la Pente Récifale Externe à Vanuatu. Port-Vila: ORSTOM. Notes et documents d'océanographie 11.

Cillaurren, E., David, G., and Grandperrin, R. (2001). Coastal Fisheries Atlas of Vanuatu. A 10-year Development Assessment 1983-1993. Paris: IRD/Agence resource limitations (both financial as well as technical) faced by the VFD as most developing small-island countries, such monitoring needs to emphasize the use of targeted fisheries questions in regular household surveys and general survey and census approaches, combined with country-wide raising factors (Zeller et al., 2015).

\section{AUTHOR CONTRIBUTIONS}

ML, Collaborated to complete the data reconstruction update to 2014, contributed country specific information, and helped write the manuscript; GD, Collaborated to complete the data reconstruction update to 2014, contributed country specific information, and helped write the manuscript; JR, Collaborated to complete the data reconstruction update to 2014, contributed country specific information, and helped write the manuscript; JK, Collaborated to complete the data reconstruction update to 2014 , contributed country specific information, and helped write the manuscript; LH, Changed the raw data to conform with the standard reconstruction methodology and practices in the Sea Around Us database, contributed to the manuscript and reviewed and edited the manuscript; DZ, Advised on methods, guided analysis, contributed to the manuscript, and reviewed and edited the manuscript.

\section{FUNDING}

The Sea Around Us is supported by the Paul G. Allen Family Foundation and the Oak Foundation. Neither funder had any influence or input into the research, data, manuscript preparation or decision to write and submit this manuscript.

\section{ACKNOWLEDGMENTS}

The authors would like to thank Daniel Pauly and Darcy Dunstan from the University of British Columbia for their technical advice, assistance and comments on the manuscript. LH and DZ acknowledge the Sea Around Us, a research initiative at the University of British Columbia supported by the Paul G. Allen Foundation and the Oak Foundation, and the Sea Around Us-Indian Ocean at the University of Western Australia. intergouvernementale de la Francophonie/Secrétariat permanent pour le Pacifique.

David, G. (1991). Pêche Villageoise et Alimentation au Vanuatu, Exploration d'un Système. Ph.D., UBO University.

David, G. (2014). Le vanuatu côté océan: la révolution bleue et les premières années de l'indépendance. J. Soc. Océan 140, 62-75. doi: 10.4000/jso.6540

David, G., and Cillaurren, E. (1988). A Survey of Village Subsistence Fishing in Vanuatu. Notes et Documents d'Océanographie 19, ORSTOM.

David, G., and Cillaurren, E. (1992). National fisheries development policy for coastal waters, small-scale village fishing, and food self-reliance in Vanuatu. Man Cult. Oceania 8, 35-58.

Devambez, L. C. (1959). Survey of Trochus Reefs in the Central and Southern Groups of the New Hebrides. Noumea: South Pacific Commission (SPC). 
Devambez, L. C. (1960). Report on a Supplementary Survey of Trochus and Green Snail Reefs in the Central and Southern Groups of the New Hebrides. Noumea: South Pacific Commission (SPC).

Fricke, R., Earle, J. L., Pyle, R. L., and Séret, B. (2011). "Checklist of the fish in Santo Island," in The Natural History of Santo (2006 Santo Expedition), eds P. Bouchet, H. Le Guyader and O. Pascal (Paris: MNHN, IRD and PNI), 383-409.

Friedman, K., Pakoa, K., Kronen, M., Chapman, L., Sauni, S., Vigliola, L., et al. (2008). Vanuatu Country Report: Profiles and Results from Survey Work at Paunangisu Village, Moso Island, Uri and Uripiv Islands and the Maskelyne Archipelago (July to December 2003). Noumea: PROCFish/C/CoFish and the Secretariat of the Pacific Community.

Gillett, R. (2010). Marine Fishery Resources of the Pacific Islands. Rome: FAO Fisheries and Aquaculture Technical Paper 537.

Grandperrin, R., and Brouard, F. (1983). Etat D'avancement des Recherches Conduites par l'ORSTOM en Matière de Pêche à Vanuatu. Notes et Documents D’océanographie 6, ORSTOM.

Harper, S., Frotté, L., Bale, S., Booth, S., and Zeller, D. (2009). "Reconstruction of total marine fisheries catches for New Caledonia (1950-2007)," in Fisheries Catch Reconstructions: Islands, Part, I, eds D. Zeller and S. Harper (Vancouver: Fisheries Centre, University of British Columbia), 67-75. Fisheries Centre Research Reports 17(5).

Jacquet, J. (2016). Is Shame Necessary? New Uses for an Old Tool. New York, NY: Vintage Books.

Jimenez, H., Dumas, P., Léopold, M., and Ferraris, J. (2011). Invertebrate harvesting on tropical urban areas: trends and impact on natural populations (New Caledonia, South Pacific). Fish. Res. 108, 195-204. doi: 10.1016/j.fishres.2010.12.021

Johannes, R. E., and Hickey, F. R. (2004). Evolution of Village-Based Marine Resource Management in Vanuatu between 1993 and 2001. Paris: Coastal region and small islands papers 15 , UNESCO.

Kulbicki, M., MouTham, G., Vigliola, L., Wantiez, L., Manaldo, E., Labrosse, P., et al. (2011). Major Coral Reef Fish Species of the South Pacific with Basic Information on their Biology and Ecology. Nouméa: SPC. CRISP-IRD Report. Available online at: http://www.ircp.pf/en/the-crisp-database/

Léopold, M. (2016). Evaluating the Harvest and Management Strategies for the Sea Cucumber Fisheries in Vanuatu. Nouméa: IRD. Projects No 4860A1 (BICH2MER) and No CS14-3007-101 (BICHLAMAR).

Léopold, M., Beckensteiner, J., Kaltavara, J., Raubani, J., and Caillon, S. (2013). Community-based management of fisheries in Vanuatu: what works? Mar. Policy 42, 167-176. doi: 10.1016/j.marpol.2013. 02.013

Marchandise, B. (1990). Méthodes Pour une Gestion Rationnelle du Stock de Trocas au Vanuatu. Nouméa: Commission du Pacifique Sud (SPC).

Naviti, W. (2005). Vanuatu Tuna Fisheries Report to the WCPFC-SC1. Port-Vila: Vanuatu Fisheries Department.

Nunoo, F. K. E., Asiedu, B., Amador, K., Belhabib, D., Lam, V. W. Y., Sumaila, U. R., et al. (2014). Marine fisheries catches in Ghana: historic reconstruction for 1950 to 2010 and current economic impacts. Rev. Fish. Sci. Aquacult. 22, 274-283. doi: 10.1080/23308249.2014. 962687

Pauly, D., Khafallah, M., Palomares, M. L. D., and Zeller, D. (in press). "Fisheries catch trends from the Arabian sea large marine ecosystem and derived status indicators, 1950-2014," in The Arabian seas: Biodiversity, Environmental Challenges and Conservation Measures, ed L. A. Jawad (Springer Verlag).
Pauly, D., and Zeller, D. (2016). Catch reconstructions reveal that global marine fisheries catches are higher than reported and declining. Nat. Commun. 7:10244. doi: 10.1038/ncomms10244

Pauly, D., and Zeller, D. (2017). Counting the fish catch - why don't the numbers match? Environ. Sci. J. Teens 1-5. Available online at: http://www. sciencejournalforkids.org/science-articles/counting-the-fish-catch-whydont-the-numbers-match

Poupin, J., and Juncker, M. (2010). A Guide to the Decapods Crustaceans of the South Pacific. Nouméa: Secretariat of the Pacific Community.

Schaan, O., Carlot, A., and N'Guyen, F. (1987). L'exploitation des Ressources en Poissons Profonds Par les Associations de Pêcheurs à Vanuatu. Port-Villa: Notes et Douments d'Océanographie 16, ORSTOM.

Seto, K., Belhabib, D., Mamie, J., Copeland, D., Vakily, J. M., Seilert, H., et al. (2017). War, fish, and foreign fleets: the marine fisheries catches of Sierra Leone 1950-2015. Mar. Policy 83, 153-163. doi: 10.1016/j.marpol.2017.05.036

Teh, L. C. L., Kinch, J., Zylich, K., and Zeller, D. (2014). "Reconstructing Papua New Guinea’s Marine Fisheries Catch, 1950-2010,” in Fisheries Centre Working Paper \# 2014-09 (Vancouver, BC: University of British Columbia).

Van Pel, H. (1956). A Survey of Fisheries in the New Hebrides with Preliminary Recommendations for their Development. Noumea: South Pacific Commision (SPC).

VFD (2009). Vanuatu Tuna Fisheries Report to the WCPFC-SC5. Port-Vila: Vanuatu Fisheries Department.

VFD (2014). Vanuatu Tuna Fisheries Report to the WCPFC-SC10. Port-Vila: Vanuatu Fisheries Department.

VFD (2015). Vanuatu Tuna Fisheries Report to the WCPFC-SC11. Port-Vila: Vanuatu Fisheries Department.

VNSO (2007). Vanuatu 2007 Census of Agriculture. Port-Vila: Vanuatu National Statistics Office.

VNSO (2009). Vanuatu 2009 National Population and Housing Census: Analytical Report, Volume 1. Port-Vila: Vanuatu National Statistics Office.

Zeller, D., Harper, S., Zylich, K., and Pauly, D. (2015). Synthesis of under-reported small-scale fisheries catch in Pacific-island waters. Coral Reefs 34, 25-39. doi: 10.1007/s00338-014-1219-1

Zeller, D., Palomares, M. L. D., Tavakolie, A., Ang, M., Belhabib, D., Cheung, W. W. L., et al. (2016). Still catching attention: Sea Around Us reconstructed global catch data, their spatial expression and public accessibility. Mar. Policy 70, 145-152. doi: 10.1016/j.marpol.2016.04.046

Zylich, K., Shon, S., Harper, S., and Zeller, D. (2014). "Reconstruction of total marine fisheries catches for the Republic of Vanuatu, 1950-2010," in Fisheries Catch Reconstructions: Islands, Part IV, eds K. Zylich, D. Zeller, M. Ang, and D. Pauly (Vancouver, BC: Fisheries Centre; University of British Columbia), 147-156. Fisheries Centre Research Reports 22(2).

Conflict of Interest Statement: The authors declare that the research was conducted in the absence of any commercial or financial relationships that could be construed as a potential conflict of interest.

Copyright (c) 2017 Léopold, David, Raubani, Kaltavara, Hood and Zeller. This is an open-access article distributed under the terms of the Creative Commons Attribution License (CC BY). The use, distribution or reproduction in other forums is permitted, provided the original author(s) or licensor are credited and that the original publication in this journal is cited, in accordance with accepted academic practice. No use, distribution or reproduction is permitted which does not comply with these terms. 